\title{
Transplantation of iPS cell-derived neural progenitors overexpressing SDF-1 $\alpha$ increases regeneration and functional recovery after ischemic stroke
}

\author{
Monica Chau ${ }^{1}$, Todd C. Deveau ${ }^{1}$, Mingke Song ${ }^{1}$, Zheng Z. Wei ${ }^{1}$, Xiaohuan Gu ${ }^{1}$, Shan \\ Ping $\mathbf{Y u}^{1}$ and Ling $\mathbf{W e i}^{1}$ \\ ${ }^{1}$ Department of Anesthesiology, Emory University School of Medicine, Atlanta, GA, USA \\ Correspondence to: Shan Ping Yu, email: spyu@emory.edu \\ Ling Wei, email: Iwei7@emory.edu \\ Keywords: ischemic stroke; iPS cells; neural progenitor cells; SDF-1; functional recovery \\ Received: June 17, $2017 \quad$ Accepted: August 07, $2017 \quad$ Published: October 31, 2017 \\ Copyright: Chav et al. This is an open-access article distributed under the terms of the Creative Commons Attribution License 3.0 \\ (CC BY 3.0), which permits unrestricted use, distribution, and reproduction in any medium, provided the original author and source \\ are credited.
}

\section{ABSTRACT}

Ischemic stroke is a leading cause of human death and disability while clinical treatments are limited. The adult brain possesses endogenous regenerative activities that may benefit tissue repair after stroke. Trophic factors such as stromal cell-derived factor 1 alpha (SDF-1 $\alpha$ ) are upregulated in the ischemic brain, which promote endogenous regeneration. The regenerative response, however, is normally insufficient. Transplantation of exogenous cells has been explored as regenerative therapies. One promising cell type for transplantation is induced pluripotent stem (iPS) cells which are cells genetically reprogrammed from adult somatic cells. We hypothesized that transplanting neural progenitor cells derived from iPS cells (iPS-NPCs) could provide cell replacement and trophic support. The trophic factor SDF-1 $\alpha$ was overexpressed in iPS-NPCs by lentiviral transduction to test if SDF-1 $\alpha$ could increase regeneration in the ischemic brain. These SDF-1 $\alpha$-iPS-NPCs were differentiated in vitro to express mature neuronal and synaptic markers. Differentiated cells expressed functional $\mathrm{Na}^{+}$and $\mathrm{K}^{+}$channels, and fired action potentials. In the oxygen glucose deprivation (OGD) test, SDF-1 $\alpha$-iPS-NPCs survived significantly better compared to control iPS-NPCs. In mice subjected to focal cerebral ischemia in the sensorimotor cortex, iPS-NPCs and SDF-1 $\alpha$-iPS-NPCs were intracranially transplanted into the ischemic cortex 7 days after stroke. Neuronal differentiation of transplanted cells was identified using NeuN 14 days after transplantation. Mice that received SDF$1 \alpha$-iPS-NPCs had greater numbers of NeuN/BrdU and Glut-1/BrdU co-labeled cells in the peri-infarct area and improved locomotion compared to the control iPS-NPC transplantation. Thus, SDF-1 $\alpha$ upregulation in transplanted cells may be a therapeutic strategy to enhance endogenous neurovascular repair after ischemic stroke in adult mice.

\section{INTRODUCTION}

Ischemic stroke is a leading cause of death and disability in the U.S and worldwide. Despite its prevalence, there is only one FDA-approved treatment for ischemic stroke, tissue plasminogen activator (tPA). However, its efficacy is restricted to a narrow therapeutic window of $4.5 \mathrm{hrs}$ after stroke so less than $5 \%$ of stroke patients have benefited from the thrombolytic treatment $[1$, 2]. Many candidate neuroprotective drugs to treat stroke in the acute phase have failed to show benefits in clinical trials. Without effective treatments, surviving stroke patients often have neurologic impairments and disabilities for months to years after stroke [3, 4]. Alternative 
strategies targeting the delayed regenerative phase have drawn increasing attention in hopes of repairing damaged brain tissues and improving functional recovery.

One avenue for regenerative therapy is through stem cell transplantation. Induced pluripotent stem (iPS) cells are derived from somatic cells and have great potential for autologous transplantation which would circumvent host immune rejection [5-8]. Using iPS cells also sidesteps the ethical limitations of obtaining pluripotent cells from human embryos. Importantly, these pluripotent stem cells can be differentiated into any neural cell type including oligodendrocytes, astrocytes, and electrophysiologically functional neurons [9-11]. Along with these advantages, we proposed that an effective stem cell therapy should utilize both exogenous and endogenous regenerative mechanisms for optimal tissue repair and functional recovery. In this investigation, we explore the effect of transplanted neural progenitors derived from iPS cells (iPS-NSCs) on tissue repair and their abilities to enhance endogenous regeneration. Furthermore, we transplanted genetically modified iPS cells to overexpress the chemoattractive factor, stromal-cell-derived factor- $1 \alpha$ (SDF-1 $\alpha$ ) for the purpose of increasing neurogenesis and angiogenesis to the lesion site for additional tissue repair and functional recovery.

In the regenerative niches such as the subgranular zone (SGZ) of the hippocampus and the subventricular zone (SZV), the adult brain has the ability to produce new progenitor cells that can become neurons and nonneuronal cells. After brain injury, this regenerative mechanism is stimulated by increased regenerative genes and trophic factors [12]. However, the endogenous response does not have sufficient regenerative capacity to fully repair damaged ischemic tissue [13]. SDF-1 $\alpha$ is a potent chemoattractive factor that is highly upregulated in the infarct after ischemic stroke $[14,15]$. Its expression peaks at 7 to 14 days post-ischemia [16]. SDF-1 $\alpha$ signaling recruits neural progenitors from the subventricular zone (SVZ) and endothelial progenitor cells to the injured area promoting local angiogenesis and neurogenesis $[15,17]$. Moreover, SDF-1 has been shown to be able to stimulate neurite growth of retinal ganglion cells and axon regeneration after optic nerve injury [18]. In the present investigation, we hypothesized that transplanted iPS-NPCs with upregulated SDF- $1 \alpha$ would promote an increase of neuronal and vascular progenitors to the ischemic region and improve the therapeutic benefits of the cell-based therapy.

\section{RESULTS}

\section{SDF-1 $\alpha$ expression during neuronal differentiation of iPS cells}

Mouse iPS cells were subjected to lentivirus transduction containing the control plasmid or the SDF-1 $\alpha$ gene overexpression plasmid (Figure 1A). The cells were selected via puromycin resistance to create a stable cell line. As a result, both the control and SDF-1 $\alpha$ stable cell populations expressed GFP and retained GFP expression during neuronal differentiation in neurospheres (Figure 1A). During the pluripotent stage (Figure 1B) and after neural differentiation with the retinoic acid (RA) protocol [10], both SDF-1 $\alpha$-upregulated and control lines retained GFP expression allowing for ease of cell visualization and quantification in tissues after transplantation. PCR analysis demonstrated that SDF- $1 \alpha$ cells (SDF-1a-iPS-NPCs) had significantly greater SDF-1 $\alpha$ expression compared to controls (Figure 1C). The ectopic upregulation of SDF$1 \alpha$ was maintained throughout the pluripotent, progenitor ( 1 day after harvest), and neuronal stages ( 5 days after harvest) of the neuronal differentiation (Figure 1C). Taken as a whole, SDF-1 expression is higher in the cultures that were infected with virus. Our results do not differentiate between neurons and other cell types in the culture expressing upregulated SDF-1.

\section{SDF-1a-iPS-NPCs differentiated into functional neurons in vitro}

Before differentiation, both the control and SDF-1a iPS cells expressed the pluripotent marker Oct3/4 (data not shown). After the RA neural induction protocol, the cells were harvested and plated for terminal differentiation on PDL/laminin-coated dishes and continuously cultured for 5 days. After the 5 days of terminal differentiation, immunocytochemical staining detected the neuronal markers, neurofilament, Tuj-1, as well as NeuN in SDF1a-iPS-NPCs and control iPS-NPCs (Figure 2A). Both cell lines exhibited the forebrain marker, FoxG1 and the synaptic markers, synapsin and SNAP25 (Figure 2B). Further, fast inward $\mathrm{Na}^{+}$currents, outward $\mathrm{K}^{+}$currents, and evoked action potentials were recorded in these cells using whole cell recordings (Figure 2C). Tetrodotoxin (TTX) selectively blocked the voltage-gated inward $\mathrm{Na}^{+}$ current (Figure 2D).

\section{Expression of SDF-1 $\alpha$ increased cell survival after a hypoxia insult in vitro}

Since SDF-1a plays a role in cell survival, we tested a pro-survival marker, Bcl-2. PCR analysis showed that Bcl-2 expression was upregulated in SDF-1a-iPS-NPCs compared to iPS-NPC control cells (Figure 3A). We thus examined whether or not SDF-1a played a role in cell survival under ischemia-like conditions. iPS-derived neurons after terminal differentiation were exposed to oxygen glucose deprivation (OGD), an in vitro model of ischemia. The OGD insult was carried out in a hypoxia chamber with $0.1 \% \mathrm{O}_{2}$ for 3 or $7 \mathrm{hrs}$ followed by $12 \mathrm{~h}$ of reoxygenation in normoxia. Viability in the OGD experiments was determined using the MTT assay. 
A

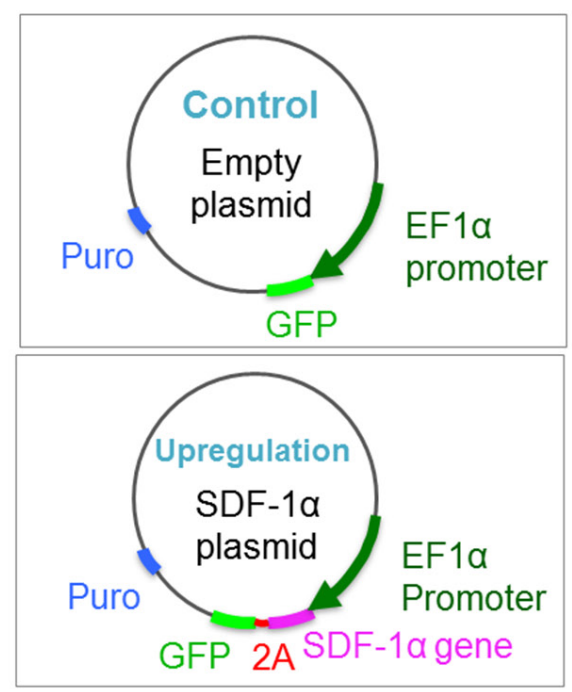

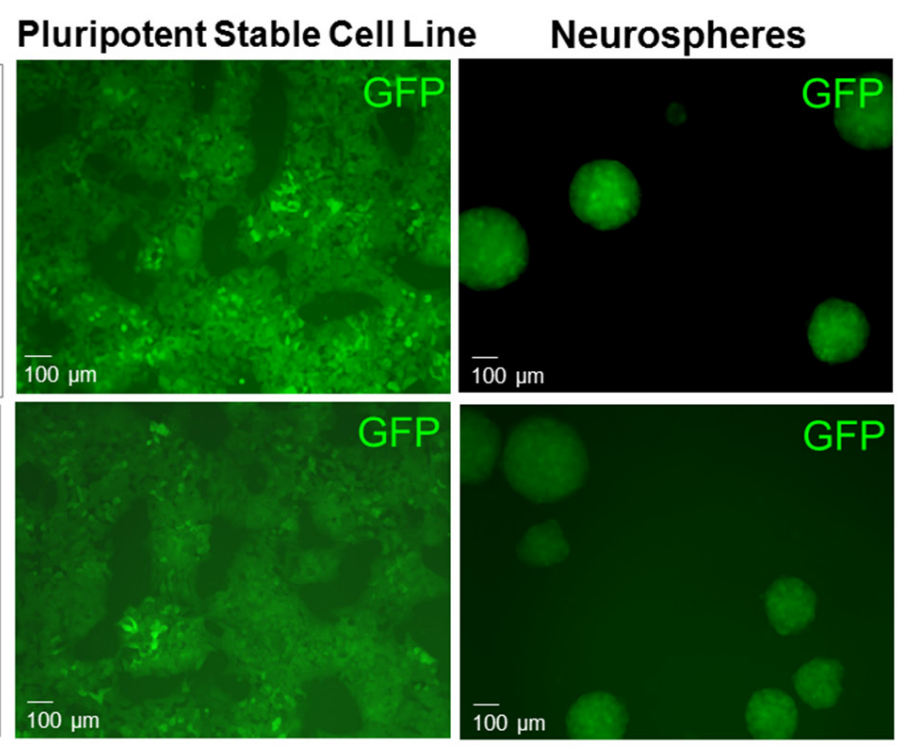

B

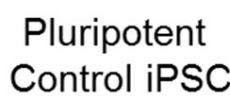

Pluripotent SDF- $1 \alpha-\mathrm{iPSC}$
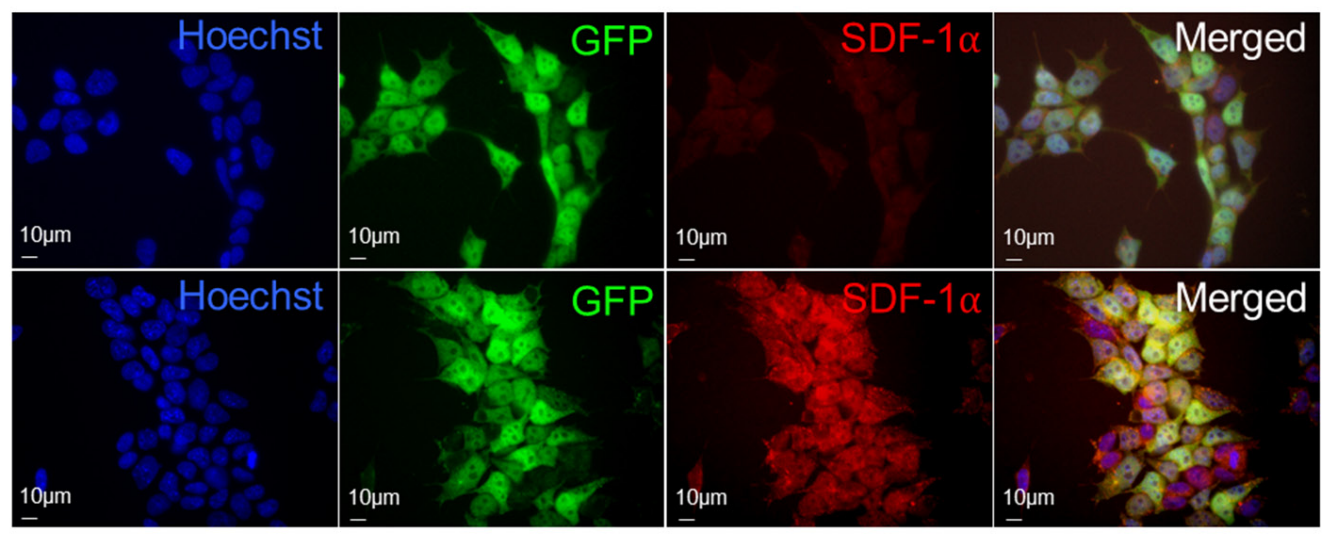

C

Pluripotent:
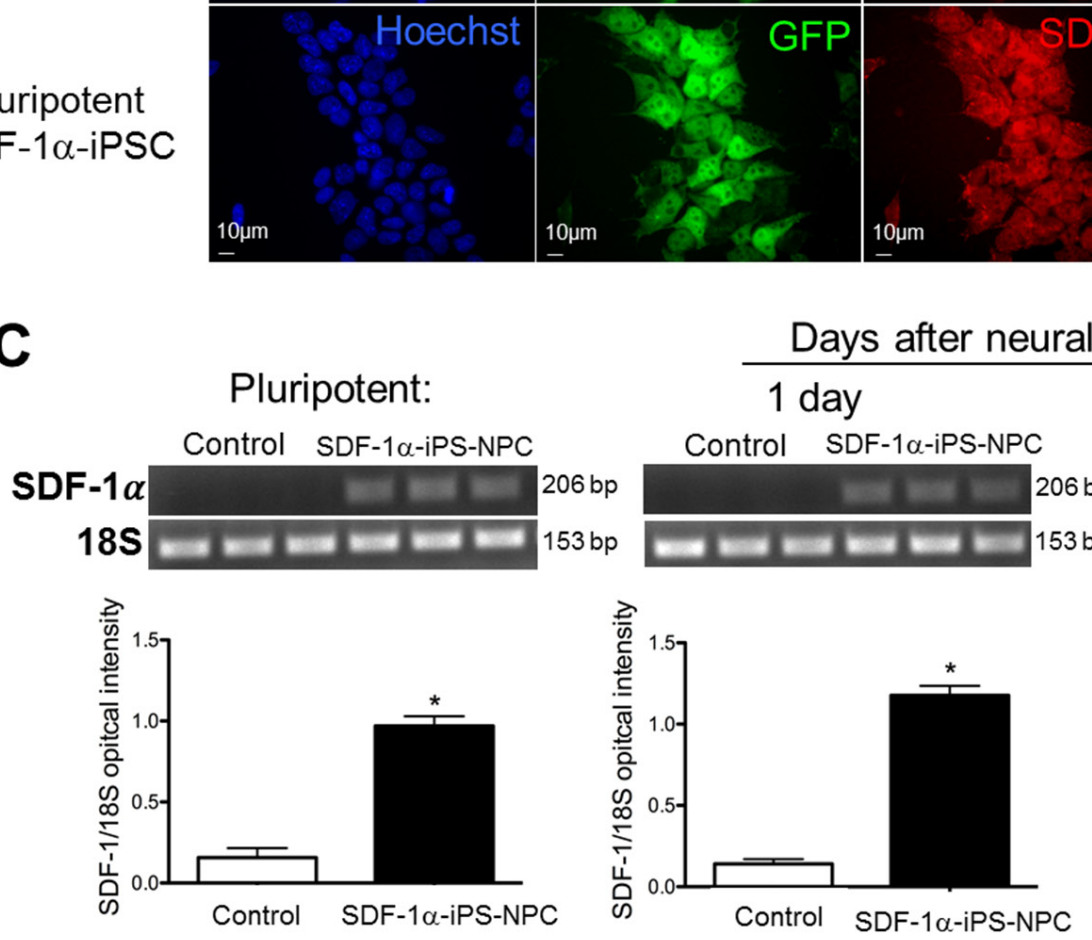

Days after neural differentiation

1 day 5 days

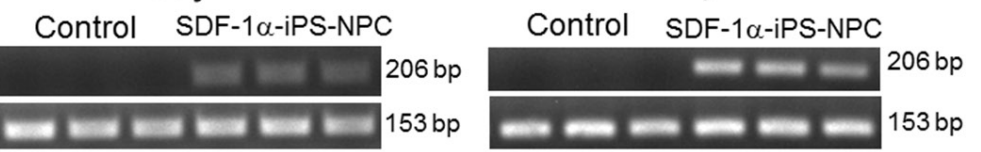

Figure 1: SDF-1 $\alpha$ expression before and after neuronal differentiation of iPS cells. (A) Lentiviral vectors were used for SDF-1 $\alpha$ ectopic overexpression. The GFP green fluorescent in naïve and neurospheres shows successful virus transfection. (B) Immunocytochemical images of progenitor cells 4 days after neural induction induced by the retinoic acid protocol. In empty vector control cells, SDF-1 $\alpha$ staining revealed basal level of endogenous SDF- $1 \alpha$ expression. Transfection of SDF-1 $\alpha$ containing vectors increased the expression of SDF-1 $\alpha$. (C) PCR analysis demonstrated that SDF-1 $\alpha$ transfected cells had significantly greater SDF-1 $\alpha$ expression compared to controls throughout the pluripotent, progenitor (1d after harvest), and neuronal stages ( $5 \mathrm{~d}$ after harvest) of differentiation. 
Compared to control iPS-NPCs, SDF-1a-iPS-NPCs exhibited greater viability after OGD (Figure 3B).

\section{SDF-1 $\alpha$ expression and neuronal differentiation of SDF-1a-iPS-NPCs in vitro and in the post- ischemic brain}

We tested if the ectopic overexpression of SDF$1 \alpha$ conferred advantages to the cells besides increased cell survival. After applying the neuronal differentiation protocol in vitro, SDF-1 $\alpha$-iPS-NPCs showed more differentiation into NeuN-positive cells compared to control iPS-NPCs (Figure 4A). There were significantly more NeuN-positive cells derived from SDF-1 overexpressing cells compared to control cells $(66.9 \%$ versus $78.5 \%$ of NeuN-positive cells from control and SDF-1 cells, respectively, $\mathrm{p}<0.05$ ) (Figure 4A).

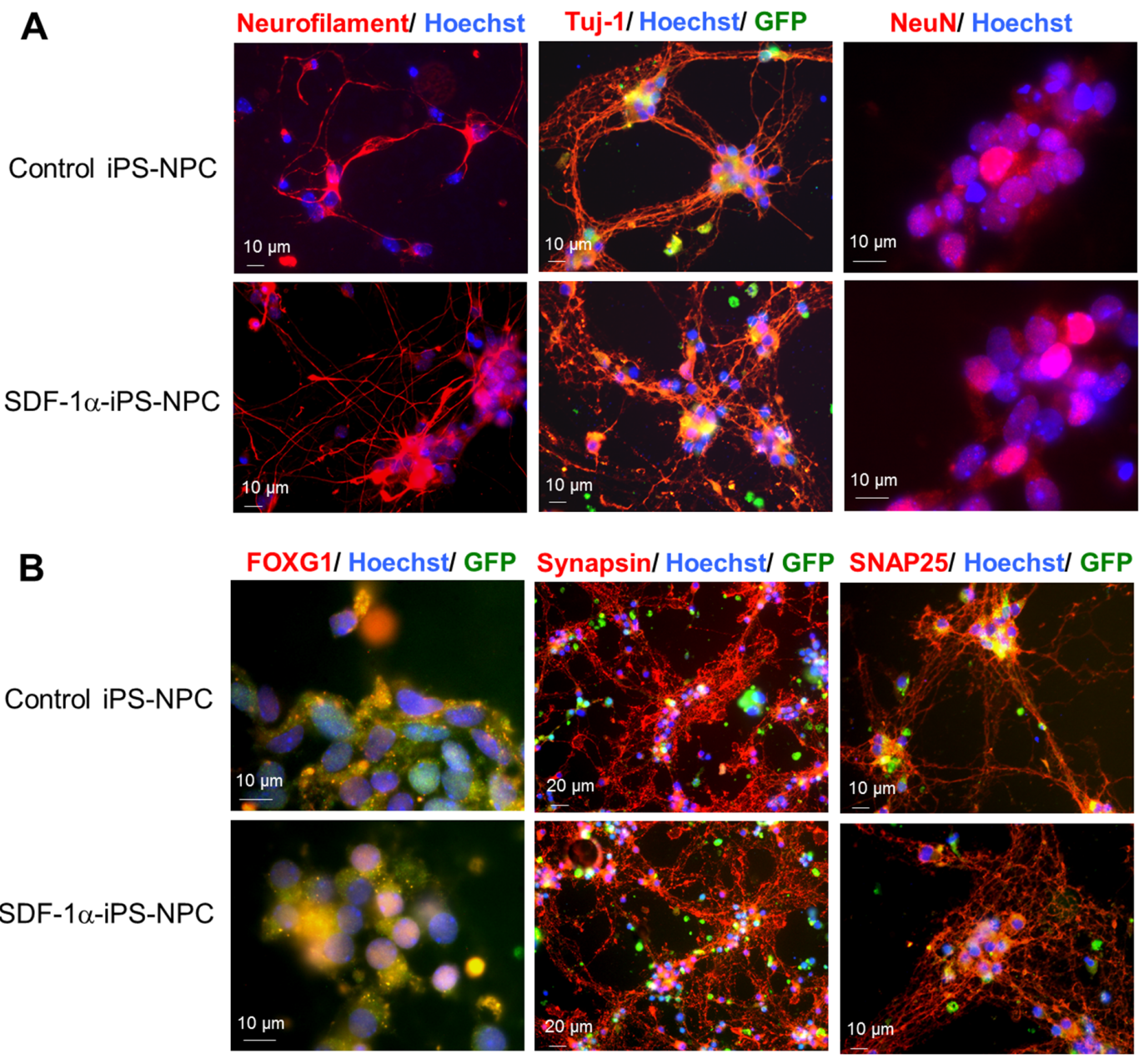

C

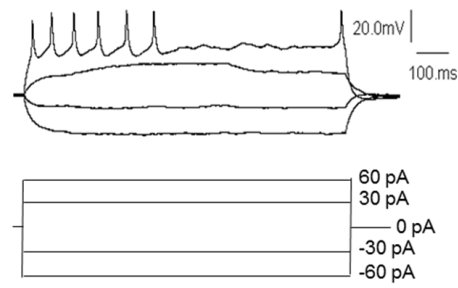

D
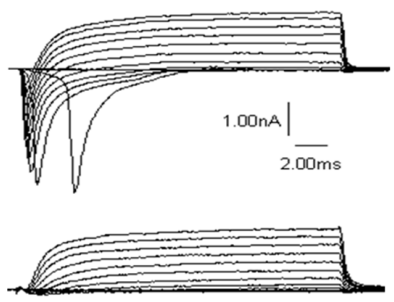

$+\mathrm{TTX}$

Figure 2: SDF-1a-iPS-NPCs differentiated into functional neurons in vitro. (A) After neuronal differentiation, SDF-1 $\alpha$ cells and control cells both expressed the mature neuronal markers, Tuj-1, neurofilament, and NeuN 5 days after differentiation. (B) Both cell lines also exhibited the forebrain marker, FoxG1 and the synaptic markers, synapsin and SNAP25. (C and D) SDF-1 $\alpha$ iPS-derived neurons exhibited evoked action potentials (C), inward sodium currents and outward potassium currents (D). Application of tetrodotoxin (TTX) attenuated the inward sodium current (D). 

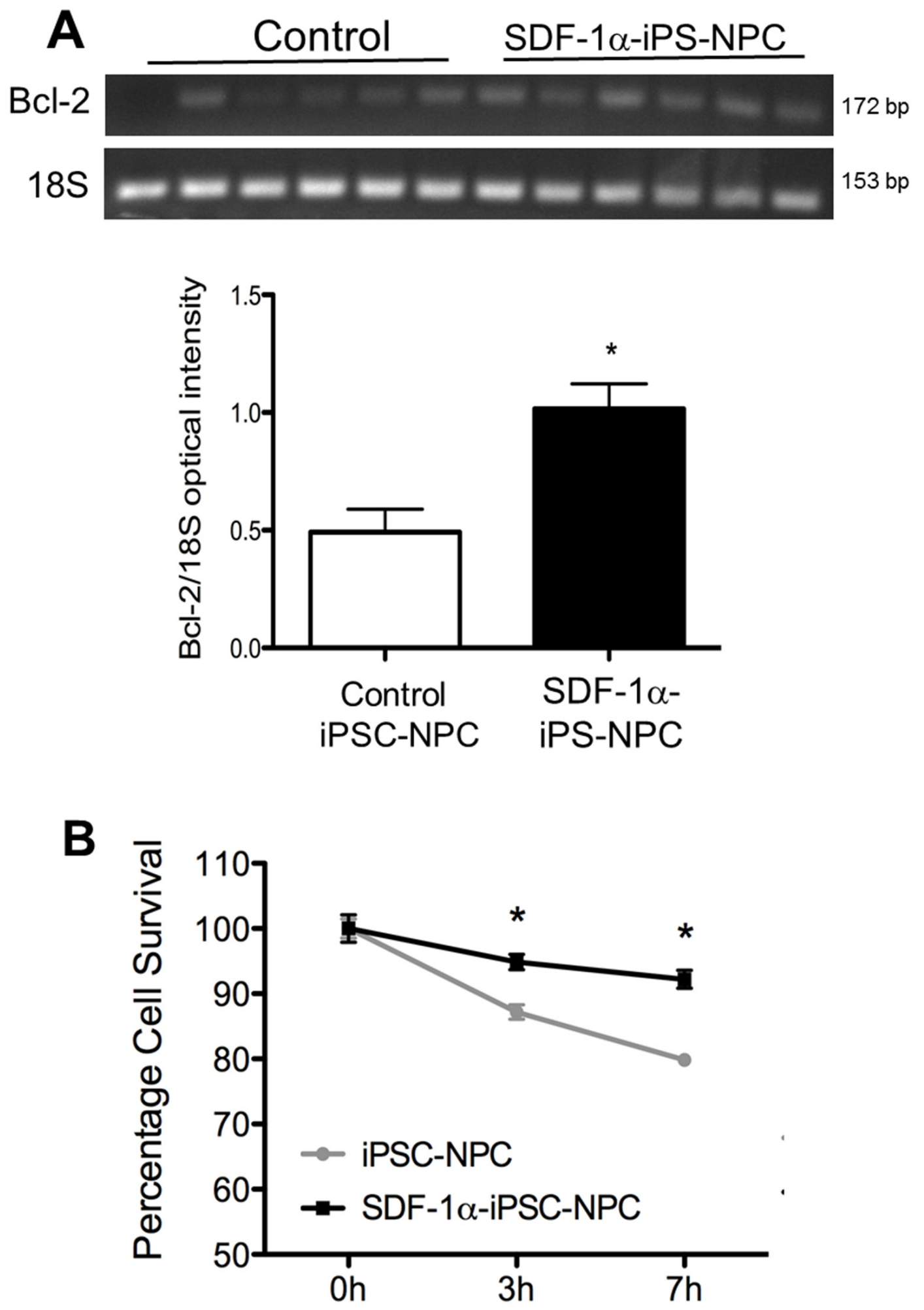

Time in Oygen Glucose Deprivation

Figure 3: SDF-1 $\alpha$ expression increased cell survival after in vitro ischemic insult. (A) PCR analysis showed that Bcl-2 was upregulated in SDF-1 $\alpha$ cells compared to control cells $\left(n=6,{ }^{*} \cdot \mathrm{p}=0.0045\right)$. (B) To test survival, cells were challenged with oxygen-glucose deprivation (OGD) in a hypoxia chamber for 3 or $7 \mathrm{hrs}$ followed by $12 \mathrm{~h}$ of "reperfusion" in normoxia. Cell viability was then measured using MTT assay. SDF-1a-iPS-NPCs exhibited greater viability after OGD compared to control cells ( $\left.n=4-6,{ }^{*} \cdot p=0.0006\right)$. The mean and standard error of the mean are plotted in the line graph. 
In our focal ischemia model, stroke was targeted to the right sensorimotor cortex of the mouse $[9,19]$. The endogenous SDF- $1 \alpha$ expression was detected in the infarct area 7 days after stroke (Figure 4B). SDF-1 $\alpha$ has been shown to be upregulated in neurons, vessels, and astrocytes after ischemia $[20,21]$. In our experiment, many SDF-1 $\alpha$ positive cells were co-labeled with GFAP staining after focal ischemia (Figure 4B).

GFP-labeled iPS-NPCs and SDF- $1 \alpha-$ iPS-NPCs (100,000 or 300,000 cells as low and high dose groups) were intracranially grafted into the peri-infarct region 7 days after stroke in the regenerative phase of stroke

\section{A}
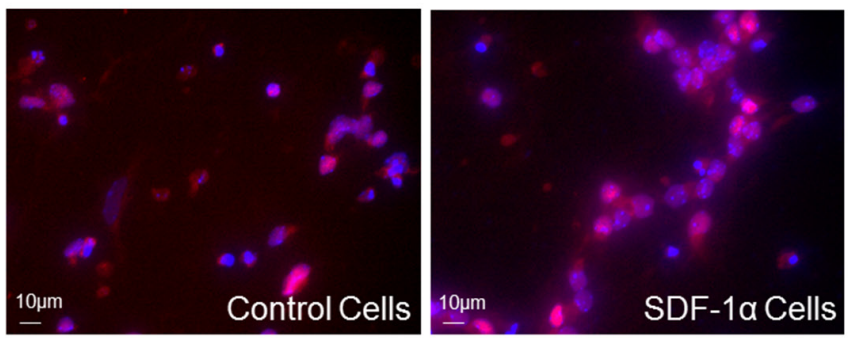

B
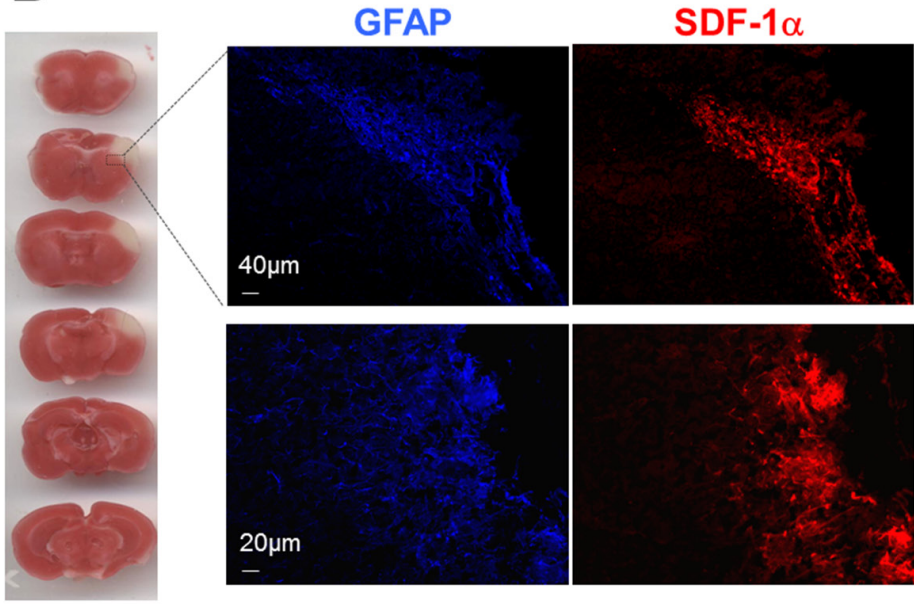

GFAPISDF-1 $1 \alpha$
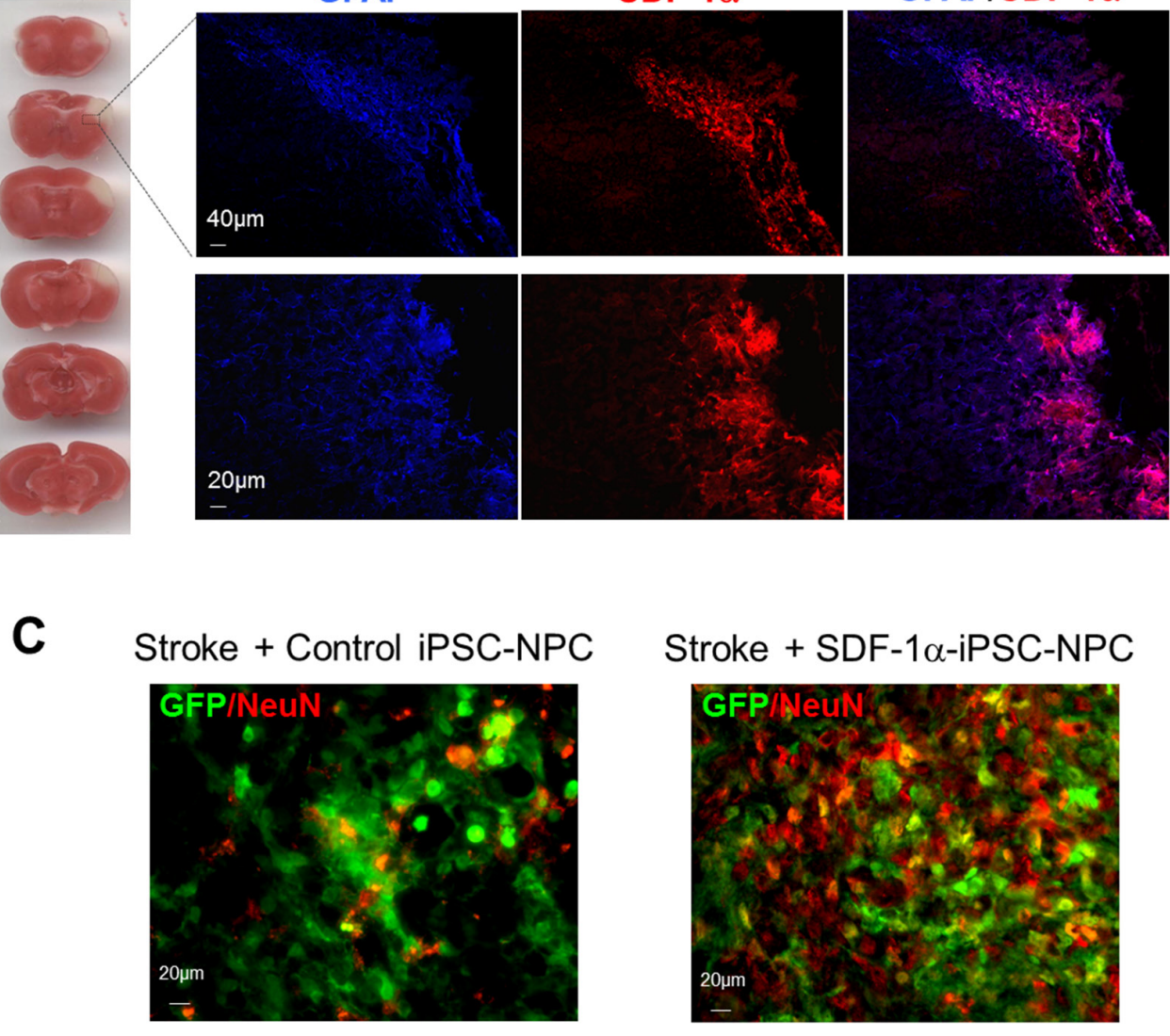

Figure 4: Expression of SDF-1 $\alpha$ and neuronal differentiation of SDF-1a-iPS-NPCs in the post-ischemic brain. (A) In an in vitro assay, neurally induced SDF- $1 \alpha$-iPS-NPCs showed an increase in differentiation into NeuN-positive cells compared to control iPSNPCs $\left(n=6,{ }^{*} \cdot p=0.037\right)$. The mean and standard error of the mean are plotted. (B) TTC staining (red) shows the cortical damage (white) in the sensorimotor cortex of the focal ischemic stroke model $24 \mathrm{hrs}$ after the insult. Seven days after stroke, SDF-1 $\alpha$ expression in the cortex was detected using immunohistochemical staining in different mice in the peri-infarct area (rectangular frame). These mice did not receive transplants. Here, TTC staining and immunofluorescence were in different mouse tissues. Many SDF-1 positive cells were also GFAP positive, consistent with astrocyte accumulation in the region at this time. (C) Two weeks after transplantation, transplantediPS-NPCs or SDF-1 $\alpha$-iPS-NPCs showed NeuN expression visualized with GFP/NeuN co-labeling in the peri-infarct area. 
$[20,21]$. This transplantation time point was selected to avoid the acute excitotoxic/inflammatory factors and brain edema during early days after stroke and targeted to improve chronic regeneration and tissue repair. Two weeks after transplantation, transplanted GFP-labelediPS-NPCs and SDF-1 $\alpha$-iPS-NPCs showed differentiation into GFP/ NeuN double-positive cells visualized in the peri-infarct area (Figure 4C).

\section{Transplantation of SDF-1 $\alpha$-iPS-NPCs increased regenerative activities in the post-stroke brain}

To label newly formed cells, the mice were injected with $\mathrm{BrdU}(50 \mathrm{mg} / \mathrm{kg} /$ day i.p) on the day of transplantation until the day of euthanasia/tissue collection. Coronal brain sections were analyzed for neurogenesis and angiogenesis in the peri-infarct area 14 days after cell transplantation. We quantified the number of co-labeled NeuN/BrdU cells and Glut-1/BrdU cells for newly formed neurons and endothelial cells respectively in the peri-infarct area of the brain (Figure 5A). Pictures were captured from 4 areas approximately 700-900 $\mu \mathrm{m}$ from the edge of the injury. Six tissue sections from each animal brain were quantified. The graphs here reflect the total number of co-labeled NeuN/BrdU and Glut-1/BrdU cells from each animal. There were significantly more Glut-1/BrdU-positive and NeuN/BrdU-positive cells in the stroke plus SDF-1 $\alpha$ iPS-NPCs transplantation group compared to the sham, stroke only, and stroke plus control iPS-NPCs groups, (Figure 5A-5C). As a control, the majority of GFP-labeled transplanted cells did not co-label with $\operatorname{BrdU}(\sim 80 \%$ for both iPS-NPCs and SDF- $1 \alpha$-iPS-NPCs, no significant difference).

\section{Transplantation of iPS-NPCs increases functional recovery}

The goal of regenerative stroke therapies is to improve functional recovery. We compared low dose (100,000 cells) and high dose $(300,000$ cells $)$ transplantations of iPS-NPCs and SDF-1a-iPS-NPCs into the ischemic brain. Using a behavior tracking system, the walking distance and the velocity of movement during a one-hour period were analyzed (Figure 6A). At 7 and 14 days after cell transplantation, the stroke mice that received high dose iPS-NPCs showed significant improvements in locomotion (Figure 6B). Furthermore, the transplantation with SDF-1a-iPS-NPCs exhibited even more enhanced movement activities (Figure 6B). The low dose transplantation group did not show significant improvements in locomotion at 7 days, but significant benefits of low and high dose transplantations into mice were seen at 14 days after stroke (Figure 6C). SDF-1aiPS-NPC transplantation again showed enhanced recovery compared to control cells.

\section{DISCUSSION}

This investigation tested the hypothesis that overexpressing SDF-1 $\alpha$ in transplanted iPS cellderived NPCs would promote endogenous regenerative mechanisms by increasing more neural and vascular progenitor cells at the ischemic injury site. This strategy combines exogenous and endogenous regenerative mechanisms to optimize the therapeutic benefits. We showed that iPS cells with SDF-1 $\alpha$ overexpression retained the ability to differentiate into electrophysiologically functional neurons in vitro. One of the benefits of SDF$1 \alpha$ expression in the iPS-NPCs is an increased tolerance to the OGD insult. Furthermore, after transplantation into the ischemic brain, GFP-labeled control and SDF-1 $\alpha$-iPSNPCs can differentiate into neurons in the peri-infarct area. To support our hypothesis, transplantation of SDF$1 \alpha$-iPS-NPCs increased the number of endogenous cells at the peri-infarct cortex, showing increased neurogenesis and angiogenesis, and improved behavioral recovery. Our data demonstrated dual benefits of transplanting SDF- $1 \alpha$-iPS-NPCs into the injury including contributing exogenous cells that could differentiate into neurons and also enhancing endogenous regeneration after ischemic stroke.

SDF-1 $\alpha$ plays pleiotropic roles in regeneration after stroke particularly in progenitor cell recruitment and cell survival $[15,22]$. The ectopic upregulation of SDF-1 $\alpha$ has been previously used as a tool to study chemotaxis in stroke, myocardial infarction, and inflammation [2325]. SDF-1 $\alpha$ expression is overexpressed endogenously in the ischemic region after stroke as a mechanism of self-repair $[15,21]$. Upon ischemia, the HIF-1 $\alpha$ oxygensensing pathway is activated which increases SDF-1 $\alpha$ expression [26]. The result is a gradient expression of SDF- $1 \alpha$ in the infarct and peri-infarct areas with SDF$1 \alpha$ expression strongest in the core $[14,15]$. Consistent with the literature, we observed an astrocytic SDF-1 $\alpha$ expression 7 days after stroke in our focal ischemic stroke model $[16,27,28]$. We reported that transplanted cells such as bone marrow mesenchymal stem cells (BMSCs) showed an effect of increasing the expression of SDF-1a in the ischemic brain [29]. In addition to the endogenous expression of SDF-1 $\alpha$, our goal was to provide the peri-infarct area with supplemental SDF-1 $\alpha$ since the endogenous regenerative mechanisms do not sufficiently repair tissue after stroke.

To support our hypothesis that iPS-NPCs have the potential to provide neuronal cell replacement, we differentiated the pluripotent cells down the neural lineage. The differentiated control and SDF-1 $\alpha$ iPS cells displayed neuronal phenotypes such as the expression of mature neuronal markers, NeuN, Tuj-1, and neurofilament demonstrating that neuronal differentiation is not impeded by SDF-1 $\alpha$ upregulation in the iPS cells. Furthermore, 

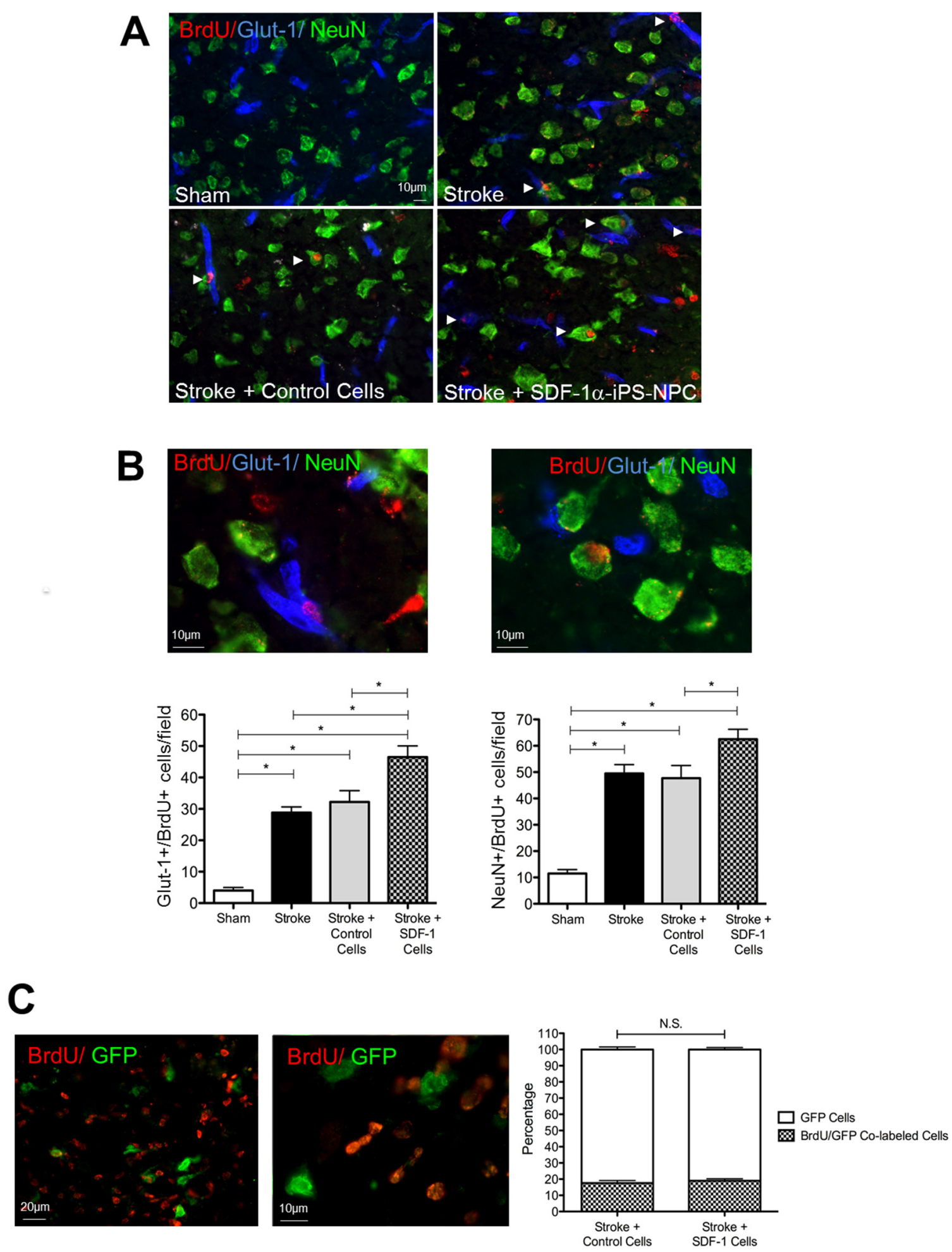

Figure 5: Transplantation of SDF-1 $\alpha$-iPS-NPCs increased regenerative activities in the post stroke brain. (A) In immunohistochemical staining, co-labeled NeuN/BrdU cells and Glut-1/BrdU cells (arrows) were used to detect newly formed neurons and endothelial cells in the peri-infarct area. (B) An enlarged image demonstrates the colocalization of NeuN (pink) and BrdU (white). (C) Pictures were captured from 4 areas 700-900 $\mu \mathrm{m}$ from the edge of the injury. Six tissue sections from each animal brain were quantified. The graphs here reflect the average number of co-labeled NeuN/BrdU and Glut-1/BrdU cells in the optical field. There were significantly more NeuN/BrdU-positive cells $\left(n=10 ;{ }^{*} \cdot \mathrm{p}=0.015\right)$ and Glut-1/BrdU-positive $\left(n=10 ;{ }^{*} \cdot \mathrm{p}=0.0008\right)$ in the SDF- $1 \alpha$ cell transplantation group compared to the sham, stroke only, and stroke + control cells groups, C. As a control, the majority of GFP-positive transplanted cells did not co-label with BrdU and there was no difference in proliferation between iPS-NPCs and SDF-1 $\alpha$-iPS-NPCs ( $\mathrm{n}=4 \mathrm{per}$ group, ${ }^{*}$. $\left.\mathrm{p}=0.5\right)$ after transplanting these cells in vivo, suggesting that the increased regeneration observed was mainly due to endogenous cells. Mean $\pm \mathrm{SEM}$. 

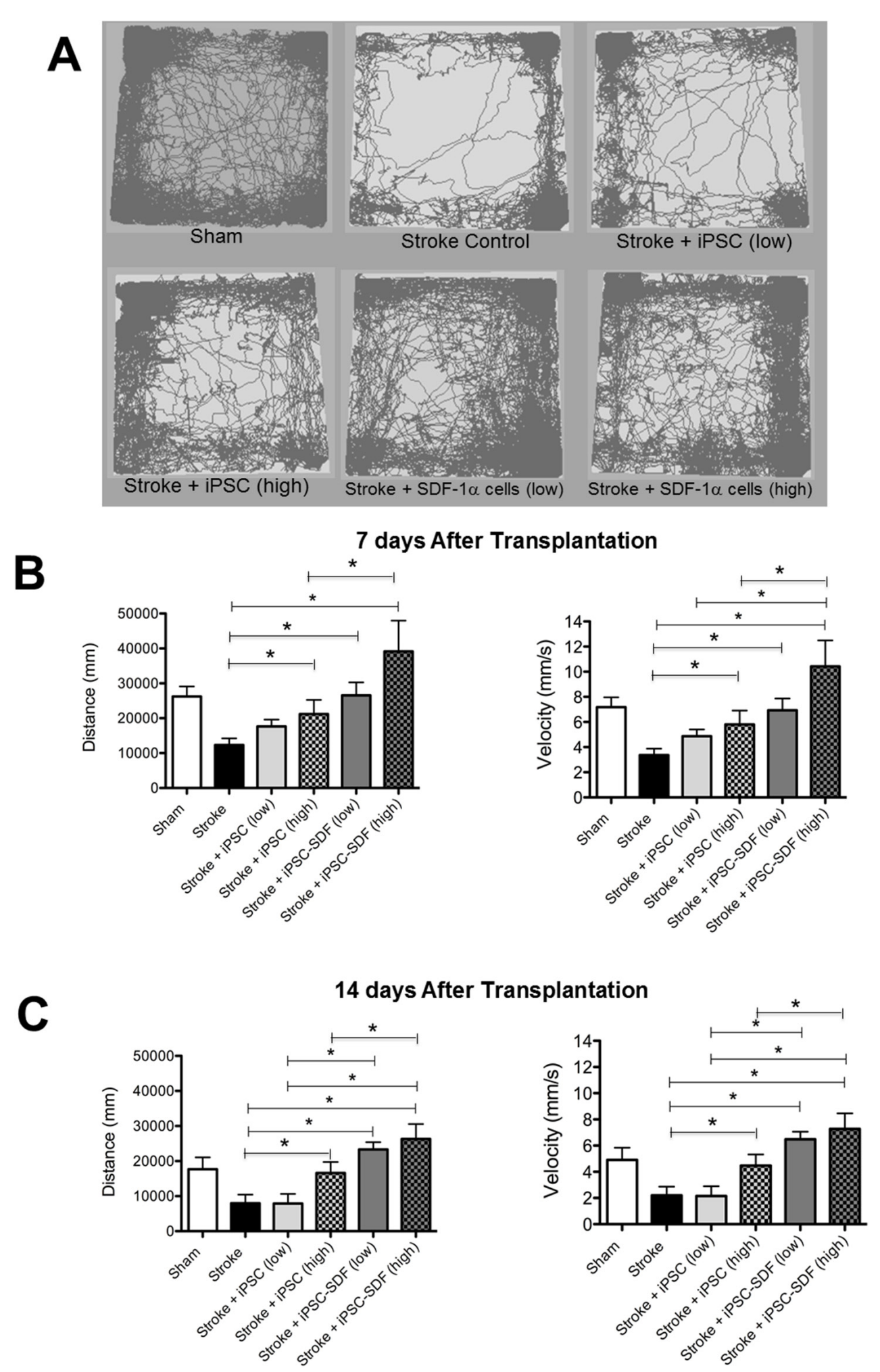

Figure 6: Transplantation of iPS-NPCs increased locomotor functional recovery after stroke. (A) Using a behavior tracking system, the distance and the velocity of walking during a one- hour period was recorded and analyzed (one-way ANOVA with Bonferroni's post-hoc correction for multiple comparisons). (B) At 7d after transplantation, mice with stroke + high dose of iPS-NPC or SDF-1a-iPSNPC transplantation exhibited significantly more movement compared to stroke only animals $\left(n=5,{ }^{*} . \mathrm{p}<0.05\right)$. There was also significant difference in the velocity of movement between stroke and stroke + high dose iPS-NPC or SDF-1a-iPS-NPC group ( $<<0.05)$. iPS-NPCs with SDF-1a overexpression showed even more increased locomotion compared to regular cells ( ${ }^{*}$. $\mathrm{p}<0.05$ ). (C) At $14 \mathrm{~d}$ after transplantation, there were significant differences between stroke and stroke plus cell transplantation (*. $\mathrm{p}<0.05)$, except the lose dose iPS-NPC group $(\mathrm{n}=5)$. Similar changes were seen with walking velocity $\left(n=5,{ }^{*} \cdot \mathrm{p}<0.05\right)$. 
control and SDF-1 $\alpha$ iPS cells can be differentiated into functional neurons exhibiting action potentials and functional $\mathrm{K}^{+}$and $\mathrm{Na}^{+}$channels. We showed before that mouse iPS cells subjected to the 4-/4+ differentiation protocol can express $\mathrm{NeuN}$ and generate action potential in about 7 days after the induction [30]. The differentiated cells also expressed FOXG1, a forebrain-specific marker appropriate for replacing cells in the cerebral cortex [31]. Both cell lines expressed synaptic markers, SNAP25 and synapsin after neuronal differentiation suggesting that these cells have the machinery to build synaptic connections.

Another advantage of upregulating SDF-1 $\alpha$ was to bolster cell survival $[32,33]$. Due to the cytotoxic nature of the stroke injury, the transplantation of exogenous cells can be challenging. Generally only a small percentage of cells survive after transplantation [34, 35]. To test cell survival, the cells were treated with ischemia-like conditions. With the OGD insult, SDF-1 $\alpha$ cells showed greater rates of survival. It is probable that SDF- $1 \alpha$ was secreted from the cells and bound to the CXCR4 receptor on neighboring cells to inactivate posttranslational cell death mechanisms such as inhibiting BAD, and also promote pro-survival genes such as Bcl-2 [36]. Cells exposed to a hydrogen peroxide $\left(\mathrm{H}_{2} \mathrm{O}_{2}\right)$ insult exhibited fewer caspase-3-positive cells and more Bcl-2 expression when SDF-1 $\alpha$ was added in vitro [37]. Furthermore, when SDF-1 $\alpha$ protein was injected into the ischemic brain, infarct size decreased and motor function increased suggesting that SDF-1 $\alpha$ contributes to neuroprotection and repair in the brain [37].

The cell transplantation was performed in the delayed phase of stroke to supplement the rising SDF$1 \alpha$ expression between 7 and 14 days when regenerative activities occur. This timing also avoided the cytotoxic milieu of the acute phase of stroke. We observed a typical increase in angiogenesis and neurogenesis after stroke [17, 20], but there was an even greater increase of angiogenesis and neurogenesis with SDF-1 $\alpha$-iPS-NPC transplantation. These findings support the role of SDF- $1 \alpha$ in regeneration after ischemia $[15,17]$. One source of neural progenitors is the SVZ from which the progenitors migrate along the corpus callosum to the cortical infarct in our model [38-40]. Endothelial progenitor cells originate from a different source; they are hematopoietic and disseminate in the body via the circulatory system [41]. Both neural progenitors and endothelial progenitor cells express the SDF- $1 \alpha$ receptor, CXCR4 $[33,42]$. SDF- $1 \alpha$ binds to this receptor on the cell to elicit G-protein coupled receptor cascades activating intracellular pathways for motility and cytoskeletal changes in the cell, such as the phosphorylation of ribosomal S6 kinase (p90 $\left.0^{\mathrm{RSK}}\right)$ involved in neurite outgrowth $[43,44]$ or the phosphorylation of c-Jun which is involved in cellular migration [45]. The regeneration we observed support the use of SDF-1 $\alpha$ upregulated iPS-NPCs for neurovascular repair [17].
The role of SDF-1 peptides has dichotomous effects in that it can attract regenerative progenitors as well immune cells such as lymphocytes and monocytes as reflecting the functional complexity of the SDF-1 family [46]. This may be modulated by isoform-specific SDF-1 expression. The SDF-1 peptide has several splice variants including SDF-1 $\alpha$ and SDF-1 $\beta$. Evidence suggests that SDF-1 $\beta$ plays a greater role as a chemoattractant for peripheral blood cells such as ciruculating leukocytes into the ischemic area whereas SDF-1 $\alpha$ has more of an effect on neuronal plasticity after stroke [16,47]. This is an example of how one gene can modulate several events after an injury, and further studies are needed to test the inflammatory effect after the transplantation of SDF- $1 \alpha$ cells.

Another caveat to introducing SDF-1 $\alpha$ iPS-NPCs into the brain is that SDF- $1 \alpha$ has also been implicated in tumorigenesis [48, 49]. In our lab, a group of 5 transplanted animals were followed for 4 months after transplantation to see whether or not tumors formed. We analyzed these tissues under $\mathrm{H} \& \mathrm{E}$ staining and no tumor formation was detected at 4 months. Tumorigenesis has been a major concern in pluripotent stem cell transplantation [50]. In this study, we transplanted the cells as differentiated neural progenitors since transplantation of undifferentiated stem cells could lead to tumorigenesis [51, 52] and lineage-restricted stem cells are better candidates [53]. One translational aspect to consider is the cell dosing and the amount of exogenous SDF- $1 \alpha$ introduced into the brain. Studies would be needed to optimize the SDF$1 \alpha$ concentration secreted by the cells, possibly using an inducible vector. Also, the cells transplanted would have to be cell-sorted for neural progenitors specifically eliminating any pluripotent cells. Our observations reveal that a small portion of transplanted cells were co-labeled with BrdU indicating that the cells could still be proliferative as neural progenitors or pluripotent cells. We started injecting BrdU on the same day that we transplanted iPS cells ( 7 days after stroke) to see the effect of the transplant on proliferation activities either on endogenous or transplanted cells. In immunostaining examinations, these BrdU positive cells did not exhibit fragmented nuclear, suggesting they were not damaged cells or cells with DNA fragmentation. Further evaluations of staining for Ki-67, PCNA, CD133, and p53 are needed [54-56] to test for tumorigenic markers.

In this investigation, we also tested the functional recovery of the mice after the transplantation of iPSNPCs. We demonstrated that mice with iPS-NPCs transplantation and SDF-1 $\alpha$ iPS-NPC transplantation had moved significantly greater distances with greater velocity compared to stroke only controls at $14 \mathrm{~d}$ after transplantation. Based on the angiogenesis and neurogenesis observed with SDF-1 $\alpha$ iPS-NPC transplanted mice, the improved functional recovery could be due to neurovascular coupling in the peri-infarct area [17]. 
Angiogenesis represents a histological correlate to the improved functional recovery by providing new blood flow as support to the injured cells in the peri-infarct area. This improvement on locomotion and overall migration may also be explained by SDF-1 $\alpha$ playing a role in modulating the firing patterns of neurons [57-59]. Currently, there has been little research on the effect of SDF- $1 \alpha$ on neuronal function, however there are some reports demonstrating SDF- $1 \alpha$ modulates the release arginine vasopressin (AVP) in the magnocellular neurons of the supraoptic nucleus (SON) and the paraventricular hypothalamic nucleus. The changes in AVP release could initiate a systemic effect affecting overall movement and health. Another report demonstrates that SDF-1 $\alpha$ enhances GABA and glutamate synaptic activity at serotonergic neurons modulating serotonin release [59]. This may be a systemic neurotransmitter correlate to explain improved locomotion.

Collectively, this data is the first to demonstrate that SDF-1 $\alpha$ iPS-NPC transplantation enhances the endogenous neurovascular regeneration and locomotor functional recovery after ischemic stroke. Furthermore, iPS-NPC transplantation also has the advantage of providing more neuronal-lineage cells into the injury area. We were able to encourage more regeneration to this area after ischemic stroke and see behavioral improvements supporting the use of trophic factor-enhanced iPS-NPCs for ischemic stroke.

\section{MATERIALS AND METHODS}

\section{Cell culture}

Pluripotent mouse iPS cells were purchased from Stemgent (Cambridge, MA). They were maintained as pluripotent cells in a growth culture medium consisting of $15 \%$ ES cell fetal bovine serum (ES Cell FBS, Gibco Life Technologies, Grand Island, NY) in Dulbecco's Modified Eagle Medium (DMEM; Corning Cellgro, Manassas, VA) with $1 \%$ non-essential amino acids, $1 \%$ penicillinstreptomycin, $0.1 \%$ beta-mercaptoethanol, and 1:10,000 leukemia inhibitory factor (LIF). Cells were passaged with $0.25 \%$ trypsin-EDTA when growth was approximately $80 \%$ confluent. Cell media was changed if the cells were not confluent enough to passage. Pluripotent cell cultures were grown on mouse embryonic fibroblast (MEF) feeder layers (Millipore, Billerica, MA) immediately after thawing. After approximately 6 passages on MEFs, the cultures were maintained in T-25, or $25 \mathrm{~cm}^{2}$ flasks precoated with $0.15 \%$ gelatin. In suspension culture, iPS cells were differentiated with the 4-/4+ (4 days without/4 days with) all trans-retinoic acid (RA, Sigma, St. Louis, $\mathrm{MO})$ protocol in media without $\operatorname{LIF}[10,60]$. To initiate differentiation, the pluripotent cells were dissociated from the flask with $0.25 \%$ trypsin without EDTA. Approximately four million dissociated iPS cells were plated in uncoated/untreated petri dishes for suspension culture in growth media. The cells formed aggregates, or embryoid bodies in suspension and the media was changed every other day throughout the differentiation protocol. Retinoic acid $\left(5 \times 10^{-7} \mathrm{M}\right)$ was added to the media for the last four days of the differentiation protocol [10]. To harvest, the aggregates were dissociated with trypsinEDTA and run through a cheesecloth filter to dissociate the remaining clumps. 100,000 or 300,000 cells were suspended in $4 \mu \mathrm{l}$ of SATO and transplanted via $2 \times 2 \mu \mathrm{l}$ injections at 2 sites in the peri-infarct cortex. The injection sites were approximately $3 \mathrm{~mm}$ lateral to bregma. Cells that were not transplanted were plated in SATO media [61] on PDL/laminin-coated dishes and were allowed to terminally differentiate in vitro.

\section{SDF-1 $\alpha$ upregulation plasmids}

The SDF-1 $\alpha$ upregulation plasmid was created by Dr. Oskar Laur at the Emory University Custom Cloning Core Facility. The human SDF- $1 \alpha$ gene was obtained from Addgene (plasmid ${ }^{* 12270)}$ ) and sub-cloned under the human elongation factor $1 \alpha(\mathrm{EF} 1 \alpha)$ promoter in the plasmid, pEGIP (Addgene, plasmid \#26777). The SDF-1 $\alpha$ upregulation plasmids were created with the backbone, pEGIP which has GFP reporter gene and puromycin resistance for selection. The SDF-1 $\alpha$ plasmid was created with the $2 \mathrm{~A}$ expression system. Control plasmids were empty vectors without the SDF- $1 \alpha$ gene and GFP expressed under the IRES system inherent to the pEGIP backbone. The empty plasmid (control) and the SDF-1 $\alpha$ plasmid were packaged into lentiviruses.

\section{Lentivirus production}

The plasmids were packaged into lentiviruses by Dr. Xinping Huang at the Emory University Viral Core. HEK 293FT cells (Invitrogen, Waltham, MA) were maintained in growth media $(4.5 \mathrm{~g} / \mathrm{L}$ glucose and Lglutamine containing DMEM supplemented with 10\% FBS and 1\% Penicillin-Streptomycin) and incubated at $37^{\circ} \mathrm{C}, 5 \% \mathrm{CO}_{2}$. The HEK $293 \mathrm{FT}$ cells were approximately $80 \%$ confluent at the time of transfection. The following mixture was prepared: $250 \mu \mathrm{g}$ of FDS1 or control plasmid $+187.5 \mu \mathrm{g}$ of pCMVdelta $8.9+75 \mu \mathrm{g}$ of pV-SVG +12 $\mathrm{ml}$ of $\mathrm{ddH}_{2} \mathrm{O}+12.5 \mathrm{ml}$ of $0.5 \mathrm{M} \mathrm{Ca} 2 \mathrm{Cl}+25 \mathrm{ml}$ of $2 \mathrm{x}$ HeBS to total volume $50 \mathrm{ml}$. This solution was shaken and incubated for $20 \mathrm{~min}$ at room temperature. Five $\mathrm{ml}$ of the mixture was added drop-wise to each dish and the dishes were returned to the incubator. Seven hours post-transfection, the media was replaced with $20 \mathrm{ml}$ of fresh media and incubated for an additional 48 hrs before harvesting. The supernatant containing the lentivirus was collected 2 days after the 48 and 72 hrs post-transfection. The supernatant was centrifuged at $500 \mathrm{xg}$ for $5 \mathrm{~min}$ at $4^{\circ} \mathrm{C}$ then passaged through a $0.45 \mu \mathrm{m}$ low protein binding 
filter. The supernatant (400 $\mathrm{ml}$ total) was loaded into six $70 \mathrm{ml}$ ultracentrifuge tubes and centrifuged at 28,000 rpm for $2 \mathrm{hrs}$ at $4^{\circ} \mathrm{C}$ in a $45 \mathrm{Ti}$ rotor (Beckman, Brea, CA). The virus pellets were resuspended in $500 \mu \mathrm{l}$ of PBS and incubated on ice for $30 \mathrm{~min}$. The six tubes of resuspended virus were combined and then loaded to a $12 \mathrm{ml} \mathrm{SW} 41$ tube. Three $\mathrm{ml}$ of $20 \%$ sucrose was added as a cushion then centrifuged at $28,000 \mathrm{rpm}$ for $2 \mathrm{hrs}$ at $4^{\circ} \mathrm{C}$ in a SW 41 rotor (Beckman). The virus pellet was resuspended in 100 $\mu \mathrm{l}$ of PBS and incubated for $2 \mathrm{hrs}$ at $4^{\circ} \mathrm{C}$. The viral titers were $1 \times 10^{8} \mathrm{IU} / \mathrm{ml}$ for the control and $1 \times 10^{7} \mathrm{IU} / \mathrm{ml}$ for the SDF-1 $\alpha$ upregulation plasmid.

\section{Stable cell line creation}

The pluripotent iPS cells were infected with the control or SDF-1 $\alpha$ lentivirus to create stable cell lines. Virus was applied to the iPS cells, and incubated for 24 hrs. Twenty-four hours after the application, GFP expression was visually confirmed in control virus and SDF-1 $\alpha$ virus cells. Cells were allowed to proliferate for 2 days before selection allowing time for the cells to express the puromycin resistance. We utilized the selection pressure of puromycin $(0.5-1 \mu \mathrm{g} / \mathrm{ml}$, Sigma $)$ and applied it directly into the cell media.

\section{Oxygen glucose deprivation and MTT assay}

As an in vitro model of ischemia, oxygen glucose deprivation (OGD) was performed on the control and SDF-1-upregulated cells. iPS cells were plated into 24-well plates at 200,000 cells/well. After adhesion to the bottom of the well overnight in the incubator at normoxic conditions, cells were incubated for 3-7 hrs in the ProOx-C-chamber system (Biospherix, Redfield, $\mathrm{NY}$ ) at $0.1-0.3 \%$ oxygen at $37^{\circ} \mathrm{C}$. Control cells were maintained in normoxic conditions. After the treatment, the cells were returned to normoxic culture conditions for a 12-hour reoxygenation period. Following 12 hours of reoxygenation, the cultures were assayed with the 3-(4,5-Dimethylthiazol-2-yl)-2,5-diphenyltetrazolium bromide (MTT) assay.

MTT solution $(25 \mu \mathrm{l}, 5 \mathrm{mg} / \mathrm{mL})$ was added to 250 $\mu \mathrm{l}$ of cell media per well and incubated for $4 \mathrm{hrs}$ at $37^{\circ} \mathrm{C}$. Two hundred fifty $\mu$ of solubilization solution was added to each well and incubated overnight. The solubilization solution consisted of $10 \%$ sodium dodecyl sulfate (SDS) in $0.01 \mathrm{M} \mathrm{HCl}$. Wells were read on a plate reader at $560 \mathrm{~nm}$ to measure colorimetric optical intensity.

\section{Immunocytochemistry}

Cultures were fixed with 4\% paraformaldehyde. Cells were washed 3 times with phosphate-buffered saline (PBS) after each step. The cells were treated with $-20^{\circ} \mathrm{C}$ ethanol/acetic acid solution, permeabilized with a $0.2 \%$ Triton-X 100 solution, and blocked with 1\% cold fish gelatin (Sigma, St. Louis, MO). The cells were incubated overnight at $4{ }^{\circ} \mathrm{C}$ with primary antibodies for Oct3/4 (sc5279, 1:200; Santa Cruz Biotechnology, Santa Cruz, CA), NeuN (MAB377 1:200; Millipore), $\beta 3$ Tubulin (Tuj-1, MMS-435P, 1:200; Covance, Princeton, NJ), neurofilament (AB9568, 1:100; Millipore), synaptosomal-associated protein 25 (SNAP-25, AB5871P, 1:100; Millipore), synapsin 1 (51-5200, 1:200; Life Technologies, Grand Island, NY), FOXG1 (1:200, Abcam, Cambridge, MA), and GFP (1:100, Polysciences, Inc., Warrington, PA). The cells were washed with PBS after the overnight antibody incubation. The corresponding secondary antibodies were applied at 1:100 for $1 \mathrm{hr}$ at room temperature (Jackson ImmunoResearch, West Grove, PA), Cells were washed with PBS and Hoechst 33342 was applied (1:20,000) and washed off. The cells were cover-slipped with Vectashield mounting media (Vector Laboratories, Burlingame, CA).

\section{Electrophysiological recordings}

iPS cell-derived neurons were recorded with wholecell patch clamp 10 days after harvest using an EPC9 amplifier (HEKA, Elektronik, Lambrecht, Germany) at room temperature. The recording external solution consisted of (mM) $135 \mathrm{NaCl}, 5 \mathrm{KCl}, 1 \mathrm{MgCl}_{2}, 2 \mathrm{CaCl}_{2}$, 10 HEPES, and 10 Glucose at a $\mathrm{pH}$ of 7.4. The electrodes used for recording were pulled from borosilicate glass pipettes (Sutter Instrument, USA) had a tip resistance between 5 and $8 \mathrm{M} \Omega$ when filled with the internal solution (mM): $140 \mathrm{KCl}, 2 \mathrm{MgCl}_{2}, 1 \mathrm{CaCl}_{2}, 2 \mathrm{Na}_{2}$ ATP, 10 EGTA, and 10 HEPES at a $\mathrm{pH}$ of 7.2. The series resistance was compensated by $60-80 \%$. Linear leak and residual capacitance currents were subtracted on-line using a P/6 protocol. Action potentials (APs) were recorded under current-clamp mode using Pulse software (HEKA, Elektronik). Tetrodotoxin (TTX, $1 \mu \mathrm{M}$ ) was applied to block voltage-gated inward sodium currents. Data were filtered at $3 \mathrm{KHz}$ and digitized at sampling rates of 20 KHz. AP amplitude was determined by measurement from the initial threshold to the peak of AP upstroke.

\section{Reverse transcriptase-polymerase chain reaction (RT-PCR)}

The total mRNA was isolated from the pluripotent, progenitor, and differentiated cells with Trizol (Invitrogen Life Technologies, $250 \mu \mathrm{l}$ per dish). $50 \mu \mathrm{l}$ of Choloroform was added to each sample. The samples were centrifuged and the upper aqueous phase was collected and RNA was precipitated with isopropyl alcohol. The samples were centrifuged and washed two times with $75 \%$ ethanol. The RNA pellet was dried and resuspended in DEPC-treated water. cDNA was created from the RNA samples using the High Capacity RNA-to-cDNA kit ${ }^{\mathrm{TM}}$ (Applied Biosystems Life technologies, Grand Island, NY). PCR reactions consisted of a mixture of Taq buffer (New England 
Biolabs, Ipswich, MA), forward and reverser primers (listed below) dNTP (10mM), Taq polymerase, water and cDNA. Electrophoresis was used to run DNA samples on a $1.8 \%$ agarose gel. Band intensity was quantified using ImageJ software (NIH, Bethesda, MD).

Primer pairs:

18S: GACTCAACACGGGAAACCTC (forward), ATGCCAGAGTCTCGTTCGTT (reverse)

Bcl-2: GCTGTGAGGGAGCAAGAATC (forward), GGTCAAGAGGGAGTGTTGGA (reverse)

SDF-1 $\alpha: \quad$ GCTCTGCATCAGTGACGGTA

(forward), CCAGGTACTCTTGGATCCAC (reverse)

\section{Focal ischemia surgery, iPS-NPC transplantation, and tissue collection}

Adult C57BL/6 male mice (25-28 g, 2-3 month-old) were housed in a climate-controlled room with a 12-hr light-dark cycle with free access to water and food. All animal procedures were approved by the Institutional Animal Care and Use Committee (IACUC) at Emory University. A total number of 57 mice were tested in this study. The mortality rate due to surgery and anesthesia failure were generally less than $10 \%$ in our animal experiments.

To induce focal cerebral ischemia in the adult mice, the mice were anesthetized with $3 \%$ isoflurane and maintained using $1.5 \%$ isoflurane supplemented with regular air during surgery. Surgery commenced when the mouse showed no response to pinches to test reflexes. After a skin incision, the skull was drilled over the distal branches of the right middle cerebral artery. The distal branches of the right middle cerebral artery (MCA) were permanently occluded and bilateral common carotid arteries (CCAs) were ligated for $7 \mathrm{~min}$ to produce an ischemia in the right sensorimotor cortex. Sham animals received skin incisions, but no arterial occlusions. Mice received solution control and cell transplantation 7 days after stroke $(n=8$ mice per group for immunostaining examinations, $n=5$ per group in behavioral tests). The mice were anesthetized as above until they were in a deep anesthetic state verified through testing the tail and paw pinch reflex. The incision over the right side of stroke was opened and the skull was thinned over the area to be injected approximately $3 \mathrm{~mm}$ lateral to bregma. iPS-NPCs (100,000 or 300,000 cells as low and high dose groups) were transplanted in $4 \mu \mathrm{l}$, divided into 2 injection sites in the peri-infarct region at a depth of $900 \mu \mathrm{m}$ from the dura to the tip of the needle. Injections were delivered slowly with a Hamilton's syringe. Ischemia injured tissue can be identified by fainter image than the surrounding tissue. Cells were injected less than $0.5 \mathrm{~mm}$ from the border of the core region. The presence and location of the cells was later confirmed with immunostaining. Stroke only control animals received $2 \times 2 \mu$ injections of SATO media. On the day of transplantation and thereafter, mice received a daily intraperitoneal (i.p.) injection of Bromodeoxyuridine (BrdU; 50 mg/kg; Sigma). At 14 days after transplantation, mice were euthanized by overdose isoflurane before decapitation to dissect tissue to flash freeze. Some animals were anesthetized for perfusion fixation for immunohistochemistry. Once the mouse was unresponsive to the pinch reflex, an incision was made along the diaphragm and two incisions were made through the ribcage on both sides of the mouse. The sternum and ribs were pulled back to expose the heart. A needle with tubing connected to a perfusion pump was inserted into the right atrium and a small cut was made in the left ventricle. Saline was pumped through the vasculature to clear the blood and then it was replaced with $10 \%$ buffered formalin. Perfusion was complete once the animal was stiff. The brain was then dissected out and post-fixed with sucrose and formalin.

\section{Immunohistochemistry}

Fresh frozen or formalin-perfused brains were sectioned at $10 \mu \mathrm{m}$ on a cryostat microtome at $-20^{\circ} \mathrm{C}$. To avoid double-counting a cell in two adjacent sections, design-based stereology was used. Every tenth section was collected such that adjacent tissues were more than $100 \mu \mathrm{m}$ apart. Tissues were then fixed with $10 \%$ buffered formalin, washed, and treated a $-20^{\circ} \mathrm{C}$ ethanol/acetic acid solution. Tissues were permeabilized with a $0.2 \%$ Triton-X 100 solution, and blocked with $1 \%$ fish gel (Sigma). Tissues were washed three times with PBS after each step. After blocking, tissues were incubated overnight at $4{ }^{\circ} \mathrm{C}$ with primary antibodies for BrdU (1:400; AbD Serotec, Hercules, CA), NeuN (1:200; Millipore), Glut1 (1:200, Millipore), and GFP (1:100, Polysciences, Inc., Warrington, PA). After washing with PBS, secondary antibodies conjugated to fluorophores were used to visualize BrdU (donkey anti-rat Cy3, 1:300; Jackson ImmunoResearch), NeuN (donkey anti-mouse Cy5, 1:200), and Collagen IV (donkey anti-goat AlexaFluor 488, 1:200; Invitrogen Life Technologies). The secondary antibodies (Jackson ImmunoResearch) were applied and incubated on the tissue for $1 \mathrm{hr}$ at room temperature and subsequently washed 3 times with PBS and coverslipped with Vectashield. Using fluorescent microscopy, 10x pictures were captured from 4 areas $700-900 \mu \mathrm{m}$ from the edge of the injury. Six tissue sections from each animal brain were quantified. NeuN/BrdU, Glut-1/BrdU, and GFP/BrdU co-labeled cells were quantified. For each animal group (sham, stroke, stroke + control cells, stroke + SDF-1 cells), $\mathrm{n}=8$ mice. Not all animals were subjected to the same staining assays.

\section{Top scan behavioral tracking}

The Top Scan software from CleverSys, Inc (Reston, VA) was used to track animal walking distance, 
and velocity in a testing chamber $(50 \mathrm{~cm} \times 50 \mathrm{~cm})$. Seven and 14 days after transplantation, an individual mouse was placed into the testing chamber and recorded by the tracking system for 1 hour. For each animal group $n=5$ mice. The data was analyzed and graphed using the Prism Graphpad software (GraphPad Software, Inc., La Jolla, CA).

\section{Statistical analysis}

Student's t-test was used for single comparisons. One-way and two-way analysis of variance (ANOVA) followed by Bonferroni's post-hoc analysis was used for multiple comparisons. Significance was defined as a p-value that was less than 0.05 and standard error of the mean (SEM) was reported with the means. Data are presented as Mean \pm SEM.

\section{Abbreviations}

iPS cell: induced pluripotent stem cell; iPS-NSC: iPS cell-derived neural progenitor cells; SDF-1 $\alpha$ : stromal cell-derived factor-1 $\alpha$; SDF-1a-iPS-NPCs: SDF-1aoverexpressing iPS cell-derived neural progenitor cells; $\mathrm{RA}$ : retinoic acid.

\section{Author contributions}

Monica Chau: Project development; Design experiments; Perform gene modulation and immunostaining and imaging experiments; Data acquisition; Data analysis; Write and revised the manuscript; Final approval of the manuscript for publication.

Todd C. Deveau: Perform cell culture, gene modification and imaging experiments, Data acquisition; Final approval of the manuscript for publication.

Mingke Song: Perform cellular/imaging and electrophysiological experiments; Data acquisition; Data analysis; Final approval of the manuscript for publication.

Zheng Z. Wei: Perform immunohistochemical and molecular experiments; Data acquisition; Data analysis; Final approval of the manuscript for publication.

Xiaohuan $\mathrm{Gu}$ : Perform animal experiments; Data acquisition; Data analysis, Final approval of the manuscript for publication.

Shan Ping Yu: Conception development; Design experiments; Data analysis and interpretation; Manuscript writing; Final approval of the manuscript for publication; Grant support to the project.

Ling Wei: Conception and project development; Design experiments; Perform immunohistochemical and imaging experiments; Data analysis and interpretation; Participating in manuscript writing; Revising the manuscript with critical comments; Final approval of the manuscript for publication; Grant support to the project.

\section{ACKNOWLEDGMENTS}

We would like to thank Dr. Xinping Huang of the Emory Virus Core and Dr. Oskar Laur of the Emory cloning core for their valuable help.

\section{CONFLICTS OF INTEREST}

The authors declare no conflicts of interest.

\section{FUNDING}

This work was supported by NIH grants NS075338 (LW), NS085568 (LW), NS091585 (LW), an AHA Postdoctoral fellowship 15POST25710112 (ZZW), and an NIH Predoctoral Fellowship T32 007480-15 (JZ).

\section{REFERENCES}

1. Zoppo D. Expansion of the time window for treatment of acute ischemic stroke with intravenous tissue plasminogen activator: a science advisory from the American Heart Association/American Stroke Association (vol 40, pg 2945, 2009). Stroke. 2010; 41:E562. https://doi.org/10.1161/ Str.0b013e3181efa8d7.

2. Adeoye O, Hornung R, Khatri P, Kleindorfer D. Recombinant tissue-type plasminogen activator use for ischemic stroke in the United States: a doubling of treatment rates over the course of 5 years. Stroke. 2011; 42:1952-5. https://doi.org/10.1161/STROKEAHA.110.612358.

3. Kwiatkowski TG, Libman RB, Frankel M, Tilley BC, Morgenstern LB, Lu M, Broderick JP, Lewandowski CA, Marler JR, Levine SR, Brott T. Effects of tissue plasminogen activator for acute ischemic stroke at one year. National Institute of Neurological Disorders and Stroke Recombinant Tissue Plasminogen Activator Stroke Study Group. N Engl J Med. 1999; 340:1781-7. https://doi. org/10.1056/NEJM199906103402302.

4. National Institute of Neurological Disorders and Stroke rt-PA Stroke Study Group. Tissue plasminogen activator for acute ischemic stroke. N Engl J Med. 1995; 333:1581-7. https://doi.org/10.1056/NEJM199512143332401.

5. Takahashi K, Yamanaka S. Induction of pluripotent stem cells from mouse embryonic and adult fibroblast cultures by defined factors. Cell. 2006; 126:663-76.

6. Takahashi K, Tanabe K, Ohnuki M, Narita M, Ichisaka T, Tomoda K, Yamanaka S. Induction of pluripotent stem cells from adult human fibroblasts by defined factors. Cell. 2007; 131:861-72.

7. Ye L, Chang JC, Lin C, Sun X, Yu J, Kan YW. Induced pluripotent stem cells offer new approach to therapy in thalassemia and sickle cell anemia and option in prenatal diagnosis in genetic diseases. Proc Natl Acad Sci U S A. 2009; 106:9826-30. 
8. Kim PG, Daley GQ. Application of induced pluripotent stem cells to hematologic disease. Cytotherapy. 2009; 11:980-9. https://doi.org/10.3109/14653240903348319.

9. Chau MJ, Deveau TC, Song M, Gu X, Chen D, Wei L. iPSC transplantation increases regeneration and functional recovery after ischemic stroke in neonatal rats. Stem Cells. 2014; 32:3075-87. https://doi.org/10.1002/stem.1802.

10. Bain G, Kitchens D, Yao M, Huettner JE, Gottlieb DI. Embryonic stem cells express neuronal properties in vitro. Dev Biol. 1995; 168:342-57. https://doi.org/10.1006/ dbio.1995.1085.

11. Reubinoff BE, Itsykson P, Turetsky T, Pera MF, Reinhartz E, Itzik A, Ben-Hur T. Neural progenitors from human embryonic stem cells. Nat Biotechnol. 2001; 19:1134-40. https://doi.org/10.1038/nbt1201-1134.

12. Zhang R, Zhang Z, Chopp M. Function of neural stem cells in ischemic brain repair processes. J Cereb Blood Flow Metab. 2016; 36:2034-43. https://doi. org/10.1177/0271678X16674487.

13. Xiong Y, Mahmood A, Chopp M. Angiogenesis, neurogenesis and brain recovery of function following injury. Curr Opin Investig Drugs. 2010; 11:298-308.

14. Li WL, Yu SP, Ogle ME, Ding XS, Wei L. Enhanced neurogenesis and cell migration following focal ischemia and peripheral stimulation in mice. Dev Neurobiol. 2008; 68:1474-86. https://doi.org/10.1002/dneu.20674.

15. Robin AM, Zhang ZG, Wang L, Zhang RL, Katakowski M, Zhang L, Wang Y, Zhang C, Chopp M. Stromal cell-derived factor 1alpha mediates neural progenitor cell motility after focal cerebral ischemia. J Cereb Blood Flow Metab. 2006; 26:125-34. https://doi.org/10.1038/sj.jcbfm.9600172.

16. Stumm RK, Rummel J, Junker V, Culmsee C, Pfeiffer M, Krieglstein J, Hollt V, Schulz S. A dual role for the SDF-1/CXCR4 chemokine receptor system in adult brain: isoform-selective regulation of SDF-1 expression modulates CXCR4-dependent neuronal plasticity and cerebral leukocyte recruitment after focal ischemia. J Neurosci. 2002; 22:5865-78.

17. Ohab JJ, Fleming S, Blesch A, Carmichael ST. A neurovascular niche for neurogenesis after stroke. J Neurosci. 2006; 26:13007-16.

18. Heskamp A, Leibinger M, Andreadaki A, Gobrecht P, Diekmann H, Fischer D. CXCL12/SDF-1 facilitates optic nerve regeneration. Neurobiol Dis. 2013; 55:76-86. https:// doi.org/10.1016/j.nbd.2013.04.001.

19. Wei L, Rovainen CM, Woolsey TA. Ministrokes in rat barrel cortex. Stroke. 1995; 26:1459-62.

20. Thored P, Arvidsson A, Cacci E, Ahlenius H, Kallur T, Darsalia V, Ekdahl CT, Kokaia Z, Lindvall O. Persistent production of neurons from adult brain stem cells during recovery after stroke. Stem Cells. 2006; 24:739-47.

21. Thored P, Wood J, Arvidsson A, Cammenga J, Kokaia Z, Lindvall O. Long-term neuroblast migration along blood vessels in an area with transient angiogenesis and increased vascularization after stroke. Stroke. 2007; 38:3032-9.

22. Guo Y, Hangoc G, Bian H, Pelus LM, Broxmeyer HE. SDF-1/CXCL12 enhances survival and chemotaxis of murine embryonic stem cells and production of primitive and definitive hematopoietic progenitor cells. Stem Cells. 2005; 23:1324-32.

23. Liu XS, Chopp M, Santra M, Hozeska-Solgot A, Zhang RL, Wang L, Teng H, Lu M, Zhang ZG. Functional response to SDF1 alpha through over-expression of CXCR4 on adult subventricular zone progenitor cells. Brain Res. 2008; 1226:18-26. https://doi.org/10.1016/j.brainres.2008.06.013.

24. Rabbany SY, Pastore J, Yamamoto M, Miller T, Rafii S, Aras R, Penn M. Continuous delivery of stromal cellderived factor-1 from alginate scaffolds accelerates wound healing. Cell Transplant. 2010; 19:399-408. https://doi. org/10.3727/096368909X481782.

25. Zhang M, Mal N, Kiedrowski M, Chacko M, Askari AT, Popovic ZB, Koc ON, Penn MS. SDF-1 expression by mesenchymal stem cells results in trophic support of cardiac myocytes after myocardial infarction. FASEB J. 2007; 21:3197-207. https://doi.org/10.1096/fj.06-6558com.

26. Ceradini DJ, Kulkarni AR, Callaghan MJ, Tepper OM, Bastidas N, Kleinman ME, Capla JM, Galiano RD, Levine JP, Gurtner GC. Progenitor cell trafficking is regulated by hypoxic gradients through HIF-1 induction of SDF-1. Nat Med. 2004; 10:858-64. https://doi.org/10.1038/nm1075.

27. Miller JT, Bartley JH, Wimborne HJ, Walker AL, Hess DC, Hill WD, Carroll JE. The neuroblast and angioblast chemotaxic factor SDF-1 (CXCL12) expression is briefly up regulated by reactive astrocytes in brain following neonatal hypoxic-ischemic injury. BMC Neurosci. 2005; 6:63. https://doi.org/10.1186/1471-2202-6-63.

28. Schonemeier B, Schulz S, Hoellt V, Stumm R. Enhanced expression of the CXC112/SDF-1 chemokine receptor CXCR7 after cerebral ischemia in the rat brain. J Neuroimmunol. 2008; 198:39-45. https://doi.org/10.1016/j. jneuroim.2008.04.010.

29. Wei L, Fraser JL, Lu ZY, Hu X, Yu SP. Transplantation of hypoxia preconditioned bone marrow mesenchymal stem cells enhances angiogenesis and neurogenesis after cerebral ischemia in rats. Neurobiol Dis. 2012; 46:635-45.

30. Mohamad O, Yu SP, Chen D, Ogle M, Song M, Wei L. Efficient neuronal differentiation of mouse ES and iPS cells using a rotary cell culture protocol. Differentiation. 2013; 86:149-58. https://doi.org/10.1016/j.diff.2013.12.002.

31. Eagleson KL, Schlueter McFadyen-Ketchum LJ, Ahrens ET, Mills PH, Does MD, Nickols J, Levitt P. Disruption of Foxg1 expression by knock-in of cre recombinase: effects on the development of the mouse telencephalon. Neuroscience. 2007; 148:385-99. https://doi.org/10.1016/j. neuroscience.2007.06.012.

32. Teicher BA, Fricker SP. CXCL12 (SDF-1)/CXCR4 pathway in cancer. Clin Cancer Res. 2010; 16:2927-31. 
33. Zhu B, Xu D, Deng X, Chen Q, Huang Y, Peng H, Li Y, Jia B, Thoreson WB, Ding W, Ding J, Zhao L, Wang Y, et al. CXCL12 enhances human neural progenitor cell survival through a CXCR7- and CXCR4-mediated endocytotic signaling pathway. Stem Cells. 2012; 30:2571-83. https:// doi.org/10.1002/stem.1239.

34. Ishibashi $\mathrm{S}$, Sakaguchi $\mathrm{M}$, Kuroiwa $\mathrm{T}$, Yamasaki $\mathrm{M}$, Kanemura Y, Shizuko I, Shimazaki T, Onodera M, Okano H, Mizusawa H. Human neural stem/progenitor cells, expanded in long-term neurosphere culture, promote functional recovery after focal ischemia in Mongolian gerbils. J Neurosci Res. 2004; 78:215-23. https://doi. org/10.1002/jnr.20246.

35. Kelly S, Bliss TM, Shah AK, Sun GH, Ma M, Foo WC, Masel J, Yenari MA, Weissman IL, Uchida N, Palmer T, Steinberg GK. Transplanted human fetal neural stem cells survive, migrate, and differentiate in ischemic rat cerebral cortex. Proc Natl Acad Sci U S A. 2004; 101:11839-44. https://doi.org/10.1073/pnas.0404474101.

36. Suzuki Y, Rahman M, Mitsuya H. Diverse transcriptional response of CD4+ $\mathrm{T}$ cells to stromal cell-derived factor SDF-1: cell survival promotion and priming effects of SDF-1 on CD4+ T cells. J Immunol. 2001; 167:3064-73.

37. Shyu WC, Lin SZ, Yen PS, Su CY, Chen DC, Wang HJ, Li H. Stromal cell-derived factor-1 alpha promotes neuroprotection, angiogenesis, and mobilization/homing of bone marrow-derived cells in stroke rats. J Pharmacol Exp Ther. 2008; 324:834-49. https://doi.org/10.1124/ jpet.107.127746.

38. Park IH, Arora N, Huo H, Maherali N, Ahfeldt T, Shimamura A, Lensch MW, Cowan C, Hochedlinger K, Daley GQ. Disease-specific induced pluripotent stem cells. Cell. 2008; 134:877-86.

39. Song M, Yu SP, Mohamad O, Cao W, Wei ZZ, Gu X, Jiang MQ, Wei L. Optogenetic stimulation of glutamatergic neuronal activity in the striatum enhances neurogenesis in the subventricular zone of normal and stroke mice. Neurobiol Dis. 2017; 98:9-24. https://doi.org/10.1016/j. nbd.2016.11.005.

40. Kernie SG, Parent JM. Forebrain neurogenesis after focal Ischemic and traumatic brain injury. Neurobiol Dis. 2010; 37:267-74. https://doi.org/10.1016/j.nbd.2009.11.002.

41. Gomperts BN, Belperio JA, Rao PN, Randell SH, Fishbein MC, Burdick MD, Strieter RM. Circulating progenitor epithelial cells traffic via CXCR4/CXCL12 in response to airway injury. J Immunol. 2006; 176:1916-27.

42. Yamaguchi J, Kusano KF, Masuo O, Kawamoto A, Silver M, Murasawa S, Bosch-Marce M, Masuda H, Losordo DW, Isner JM, Asahara T. Stromal cell-derived factor-1 effects on ex vivo expanded endothelial progenitor cell recruitment for ischemic neovascularization. Circulation. 2003; 107:1322-8.

43. Suzuki Y, Rahman M, Mitsuya H. Diverse transcriptional response of CD4(+) T cells to stromal cell-derived factor
(SDF)-1: cell survival promotion and priming effects of SDF-1 on CD4(+) T cells. J Immunol. 2001; 167:3064-73.

44. Wong EV, Schaefer AW, Landreth G, Lemmon V. Involvement of p90rsk in neurite outgrowth mediated by the cell adhesion molecule L1. J Biol Chem. 1996; 271:18217-23.

45. Li G, Gustafson-Brown C, Hanks SK, Nason K, Arbeit JM, Pogliano K, Wisdom RM, Johnson RS. c-Jun is essential for organization of the epidermal leading edge. Dev Cell. 2003; 4:865-77.

46. Bleul CC, Fuhlbrigge RC, Casasnovas JM, Aiuti A, Springer TA. A highly efficacious lymphocyte chemoattractant, stromal cell-derived factor 1 (SDF-1). J Exp Med. 1996; 184:1101-9.

47. Janowski M. Functional diversity of SDF-1 splicing variants. Cell Adh Migr. 2009; 3:243-9.

48. Wang SC, Hong JH, Hsueh C, Chiang CS. Tumorsecreted SDF-1 promotes glioma invasiveness and TAM tropism toward hypoxia in a murine astrocytoma model. Lab Invest. 2012; 92:151-62. https://doi.org/10.1038/ labinvest.2011.128.

49. Sun YX, Schneider A, Jung Y, Wang J, Dai J, Wang J, Cook K, Osman NI, Koh-Paige AJ, Shim H, Pienta KJ, Keller ET, McCauley LK, et al. Skeletal localization and neutralization of the SDF-1(CXCL12)/CXCR4 axis blocks prostate cancer metastasis and growth in osseous sites in vivo. $\mathrm{J}$ Bone Miner Res. 2005; 20:318-29. https://doi.org/10.1359/ JBMR.041109.

50. Dressel R, Schindehutte J, Kuhlmann T, Elsner L, Novota P, Baier PC, Schillert A, Bickeboller H, Herrmann T, Trenkwalder C, Paulus W, Mansouri A. The tumorigenicity of mouse embryonic stem cells and in vitro differentiated neuronal cells is controlled by the recipients' immune response. PLoS One. 2008; 3:e2622. https://doi. org/10.1371/journal.pone.0002622.

51. Kawai H, Yamashita T, Ohta Y, Deguchi K, Nagotani S, Zhang $\mathrm{X}$, Ikeda Y, Matsuura T, Abe K. Tridermal tumorigenesis of induced pluripotent stem cells transplanted in ischemic brain. J Cereb Blood Flow Metab. 2010; 30:1487-93.

52. Nishimori M, Yakushiji H, Mori M, Miyamoto T, Yaguchi T, Ohno S, Miyake Y, Sakaguchi T, Ueda M, Ohno E. Tumorigenesis in cells derived from induced pluripotent stem cells. Hum Cell. 2014; 27:29-35. https://doi. org/10.1007/s13577-013-0078-3.

53. Liao MC, Diaconu M, Monecke S, Collombat $\mathrm{P}$, Timaeus C, Kuhlmann T, Paulus W, Trenkwalder C, Dressel R, Mansouri A. Embryonic stem cell-derived neural progenitors as non-tumorigenic source for dopaminergic neurons. World J Stem Cells. 2014; 6:248-55. https://doi. org/10.4252/wjsc.v6.i2.248.

54. Moore N, Lyle S. Quiescent, slow-cycling stem cell populations in cancer: a review of the evidence and discussion of significance. J Oncol. 2011. https://doi. org/10.1155/2011/396076. 
55. Sathi GA, Tamamura R, Tsujigiwa H, Katase N, Lefeuvre M, Siar CH, Matsuda H, Nagatsuka H. Analysis of immunoexpression of common cancer stem cell markers in ameloblastoma. Exp Ther Med. 2012; 3:397-402. https:// doi.org/10.3892/etm.2011.437.

56. Zhang M, Song $\mathrm{T}$, Yang L, Chen R, Wu L, Yang Z, Fang J. Nestin and CD133: valuable stem cell-specific markers for determining clinical outcome of glioma patients. J Exp Clin Cancer Res. 2008; 27:85. https://doi. org/10.1186/1756-9966-27-85.

57. Bhattacharyya BJ, Banisadr G, Jung H, Ren D, Cronshaw DG, Zou Y, Miller RJ. The chemokine stromal cell-derived factor-1 regulates GABAergic inputs to neural progenitors in the postnatal dentate gyrus. J Neurosci. 2008; 28:672030. https://doi.org/10.1523/JNEUROSCI.1677-08.2008.

58. Callewaere C, Banisadr G, Desarmenien MG, Mechighel P, Kitabgi P, Rostene WH, Melik Parsadaniantz S. The chemokine SDF-1/CXCL12 modulates the firing pattern of vasopressin neurons and counteracts induced vasopressin release through CXCR4. Proc Natl Acad Sci U S A. 2006; 103:8221-6. https://doi.org/10.1073/pnas.0602620103.

59. Heinisch S, Kirby LG. SDF-1alpha/CXCL12 enhances GABA and glutamate synaptic activity at serotonin neurons in the rat dorsal raphe nucleus. Neuropharmacology. 2010; 58:501-14. https://doi.org/10.1016/j. neuropharm.2009.08.022.

60. Bain G, Ray WJ, Yao M, Gottlieb DI. Retinoic acid promotes neural and represses mesodermal gene expression in mouse embryonic stem cells in culture. Biochem Biophys Res Commun. 1996; 223:691-4. https://doi.org/10.1006/ bbrc.1996.0957.

61. Bottenstein JE, Sato GH. Growth of a rat neuroblastoma cell line in serum-free supplemented medium. Proc Natl Acad Sci U S A. 1979; 76:514-7. 